GRASAS Y ACEITES $72(2)$

April-June 2021, e407

ISSN-L: 0017-3495

https://doi.org/10.3989/gya.1259192

\title{
Inoculation with acetic acid bacteria improves the quality of natural green table olives
}

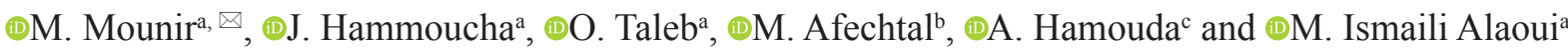 \\ aDepartment of Food Science and Nutrition, Hassan II Institute of Agronomy and Veterinary Medicine, PB Box 6202, Rabat, Morocco \\ bLaboratory of Virology, National Institute for Agricultural Research (INRA), Kénitra, Morocco \\ 'Department of Applied Statistics, Hassan II Institute of Agronomy and Veterinary Medicine, PB Box 6202 Rabat, Morocco. \\ ${ }^{\square}$ Corresponding author: mounirmajid@gmail.com
}

Submitted: 22 December 2019; Accepted: 29 April 2020; Published online: 07 June 2021

\begin{abstract}
SUMMARY: This study aims to develop a method for the preparation of natural table olives using locally selected microorganisms and without resorting to the usual techniques which employ lye treatment and acids. The effects of parameters, such as lye treatment, inoculation with yeasts, substitution of organic acids with vinegar and/or acetic acid bacteria, and finally alternating aeration have been assessed. Four different combinations were applied to the "Picholine marocaine" olive variety using indigenous strains, namely Lactobacillus plantarum S1, Saccharomyces cerevisiae LD01 and Acetobacter pasteurianus KU710511 (CV01) isolated respectively from olive brine, Bouslikhen dates and Cactus. Two control tests, referring to traditional and industrial processes, were used as references. Microbial and physicochemical tests showed that the L3V combination (inoculated with A. pasteurianus KU710511 and L. plantarum S1 under the optimal growth conditions of the Acetic Acid Bacteria (AAB) strain with $6 \% \mathrm{NaCl}$ ) was found to be favorable for the growth of the Lactic Acid Bacteria (LAB) strain which plays the key role in olive fermentation. This result was confirmed by sensory evaluation, placing $\mathrm{L} 3 \mathrm{~V}$ at the top of the evaluated samples, surpassing the industrial one where a chemical debittering treatment with lye was used. In addition, alternating aeration served to increase the microbial biomass of both AAB and LAB strains along with Saccharomyces cerevisiae $\mathrm{LD} 01$ strain, but also to use lower concentration of $\mathrm{NaCl}$ and to reduce the deterioration of olives compared to the anaerobic fermentation process. Finally, a mixed starter containing the three strains was prepared in a 10-L Lab-fermenter from the L3V sample in order to improve it in subsequent studies. The prepared starter mixture could be suitable for use as a parental strain to prepare table olives for artisan and industrial application in Morocco.
\end{abstract}

KEYWORDS: Acetobacter pasteurianus; Aerobic fermentation; Lactobacillus plantarum; Mix starter; Natural table olives; Saccharomyces cerevisiae

RESUMEN: La inoculación con bacterias del ácido acético mejora la calidad de las aceitunas de mesa verdes naturales. Este estudio tiene como objetivo desarrollar un método para la preparación de aceitunas de mesa naturales utilizando microorganismos seleccionados localmente y sin recurrir a las técnicas habituales que utilizan el tratamiento con lejía y ácidos. Se han evaluado los efectos de parámetros como el tratamiento con lejía, la inoculación con levaduras, la sustitución de ácidos orgánicos por bacterias de vinagre y/o ácido acético, y finalmente la aireación alterna. Se ensayaron cuatro combinaciones diferentes en la variedad de aceituna «Picholine marocaine» utilizando cepas autóctonas, como Lactobacillus plantarum S1, Saccharomyces cerevisiae LD01 y Acetobacter pasteurianus KU710511 (CV01) aisladas respectivamente de salmuera de aceitunas, Bouslikhen y Cactus. Se utilizaron como referencia dos pruebas de control, referidas a procesos tradicionales e industriales. Las pruebas microbianas y fisicoquímicas mostraron que la combinación L3V (inoculada con A. pasteurianus KU710511 y L. plantarum S1 en las condiciones óptimas de crecimiento de la bacteria del ácido acético (AAB) con $\mathrm{NaCl}$ al 6\%) resultó ser favorable para el crecimiento del Láctico. Las cepas de bacterias ácidas (LAB) juegan un papel clave en la fermentación de las aceitunas. Este resultado fue confirmado por la evaluación sensorial colocando L3V en la parte superior de las muestras evaluadas, superando a la industrial, donde se usó un tratamiento de eliminación química con lejía. Además, la aireación alterna permitió aumentar la biomasa microbiana de las cepas AAB y LAB junto con la cepa Saccharomyces cerevisiae LD01, también usar una concentración más baja de $\mathrm{NaCl}$ y reducir el deterioro de las aceitunas, en comparación con la operación de fermentación anaerobia. Finalmente, se preparó un iniciador mixto que contenía las tres cepas en un fermentador de laboratorio de 10-L a partir de la muestra L3V con el objeto de mejorarlo en los estudios posteriores. El iniciador de mezcla preparado podría ser adecuado para usarse como una cepa parental para preparar aceitunas de mesa para aplicaciones artesanales e industriales en Marruecos.

PALABRAS CLAVE: Aceitunas de mesa naturales; Acetobacter pasteurianus; Fermentación aerobia; Lactobacillus plantarum; Mezcla iniciadora; Saccharomyces cerevisiae 
Citation/Cómo citar este artículo: Mounir M, Hammoucha J, Taleb O, Afechtal M, Hamouda A, Ismaili Alaoui M. 2021. Inoculation with acetic acid bacteria improves the quality of natural green table olives. Grasas Aceites 72 (2), e407. https://doi.org/10.3989/ gya. 1259192

Copyright: (C2021 CSIC. This is an open-access article distributed under the terms of the Creative Commons Attribution 4.0 International (CC BY 4.0) License.

\section{INTRODUCTION}

The olive tree (Olea europaea L.) constitutes an economic and social resource for the development of the populations of the zones where it is cultivated. The growing demand for olive oil and table olives has created favorable conditions for a more efficient expansion of its cultivation, accompanied in many countries by specific development programs (Fernandez Escobar et al., 2013). In Morocco, the olive sector is supported by the Green Morocco Plan launched in 2008. Recent statistics provided by the Moroccan agriculture department (2019) show that olive orchards cover about 1.1 million ha, distributed in irrigated lowlands at $39 \%$, mountain areas at $36 \%$ and rainfed areas at $25 \%$. Moreover, Morocco occupies one of the top positions among exporters of table olives in the world. According to the Ministry of Agriculture and Maritime Fisheries, during the $2013 / 2014$ season, the domestic production was in the order of 1,6 million tons of olives, including 120,000 tons of table olives for the same period (7.6\% total olive production) (Anon, 2016).

Table olives, which are the most widespread fermented vegetables in Mediterranean countries, have a great economic significance as a food commodity. Their high nutritional value, the content in bioactive compounds, dietary fibers, fatty acid composition and antioxidants make table olives a valuable functional food (Campus et al., 2018). Green table olives are considered the most popular fermented vegetable commodity in Morocco. They constitute a major agro-industrial sector in the country's economic development (Rokni et al., 2015).

Olives are usually harvested at different stages of maturity and then processed to eliminate the bitter taste due to the glucoside named oleuropein. The green table olive de-bittering process can be accomplished in two ways: a) The Spanish-style method, i.e. using a lye treatment prior to fermentation, and $b$ ) the natural method (Sánchez Gómez et al., 2006). The Spanish style (the most common conventional preparation), consists of an alkaline treatment with sodium hydroxide, followed by several water washings of the fruits to remove residual lye. Then, the fermentation is continued in the brine from an initial salt concentration of $10-11 \%$ to reach the value of $5-6 \%$ of $\mathrm{NaCl}$ at equilibrium. The Californian style is quite distinct from that used for any other style of table olive, as there is no fermentation step. In this method, olives are subjected to a lye treatment $(0,5$ to $2 \% \mathrm{NaOH}$ ), followed by darkening with ferrous gluconate or ferrous lactate. Then, the olives are bottled or canned in brine and pasteurized or sterilized (Colmagro et al., 2001; Marsilio et al., 2001). In the other hand, the natural method, also known as "Greek style", does not require any lye treatment of the fruit, which is placed directly into the brine $(8-14 \% \mathrm{NaCl}$ and $\mathrm{pH}$ between 4.0 and 4.2), where fermentation takes place (Colmagro et al., 2001). In this case, the hydrolysis of oleuropein is attributed to the enzymatic reaction of $\beta$-glucosidase and esterase produced by the microorganisms (Amer et al., 2017).

Among the main lactic acid fermented vegetable products, i.e. cucumbers, cabbages and olives, Spanish-style green-olives are the most economically important in Morocco. This method is the most widely used for making green olives on an industrial scale. It is based on the alkaline treatment of olives to eliminate oleuropein, the agent responsible for the bitterness of the fruits of the olive tree (Ramírez et al., 2017). After de-bittering, the olives undergo successive washes to remove residual lye. The treatment consists generally of (a) lye treatment 1.5 à $2 \% \mathrm{NaOH}$ for $8-12 \mathrm{~h}$ at $24-25^{\circ} \mathrm{C}$; (b) washing by tap water for $14-15 \mathrm{~h}$ in two or three soakings, and (c) brining in $10-12 \% \mathrm{NaCl}$ (El-Khaloui and Nouri, 2007; Chemonics International, 2007).

Although the Spanish-style method is a fast process, it presents some drawbacks as well for the producer (lye and washing water expenses), 
for the consumer (risk of the chemical residues and the deterioration of the nutritional value of the treated olives) (Shahidi and Kiritsakis, 2017) and for the environment (releases of high quantities of wastewater of high organic matter, high phenolic content, high salinity and conductivity). Indeed, this process causes a strong degradation of oleuropein, which constitutes a significant loss in the nutritional value of de-bittered olives (Rokni et al., 2015). Recently, several sources reported the possibility of use of unauthorized acids by producers such as sulfuric acid to quickly neutralize the lye residue after the de-bittering of olives. This is done in order to reduce the time and cost of washing and obtain more profit (Faid, 2018). Hence, it could be important to further develop the sector by using natural table olives to overcome the drawbacks mentioned above. Natural table olives are harvested at the green-yellow stage, or fully ripened, previously washed and graded, then submerged into $\mathrm{NaCl}$ solutions $(6-10 \% \mathrm{w} / \mathrm{v})$, where fermentation takes place, mainly due to the metabolism of autochthonous microbiota (Campus et al., 2018). Yeasts and LAB control the progress of fermentation since they are more sensitive to salt concentration and the acidification of brines which are determined by metabolic activity exerted mainly by LAB (Campus et al., 2018). On the other hand, acetic acid bacteria (AAB) can also be associated with olives and olive products, in which they can play several roles (Kavroulakis and Ntougias, 2011; Valero et al., 2017). Acetobacter pasteurianus is one of the acetic acid bacteria (AAB) which have the capacity to incompletely oxidize ethanol as a substrate to produce acetic acid. For this reason, AAB are often involved, either directly or indirectly, in the fermentation of food and drinks (Cleenwerck and De Vos, 2008). It has been perfectly established that producers of table olives use organic acids, such as lactic, citric and also acetic acid, in order to favor the rapid start of fermentation and avoid the excessive increase in $\mathrm{pH}$ at the beginning of fermentation (Degirmencioglu, 2016). It has also been reported that vinegar may be added to the brine solution to preserve the olives, adjust the $\mathrm{pH}$, and impart a particular flavor (Colmagro, 2001). Thus, following our research, it seemed appropriate to consider three species of microorganisms: Lactobacillus plantarum S1,
Saccharomyces cerevisiae LD01 and Acetobacter pasteurianus KU710511 CV01 isolated from Morocco (Mounir et al., 2016a; Mounir et al., 2016b; Mounir et al., 2016c; Mounir et al., 2018)

The overall objective of our work was to develop a method for the preparation of natural table olives using locally selected microorganisms and without resorting to the usual techniques. This objective involves optimizing the synergy conditions between the selected microorganisms. To do this, ten tests were carried out (on washed and sorted olives) so that we could study the effect of the de-bittering, the effect of inoculation by yeasts, the effect of the substitution of organic acids with vinegar, the effect of the substitution of organic acids with acetic bacteria and finally the effect of alternating aeration. The monitoring of physicochemical and microbiological parameters and organoleptic evaluation were carried out to judge the quality of the olives produced.

\section{MATERIALS AND METHODS}

\subsection{Olives and microorganisms}

The olives used in our study were turning color olives of the Picholine Marocaine variety, collected from the region of Beni Mellal-Khenif (central Morocco), renowned for olive growing. The olives were kept in tap water during transport from the places where they were collected to the laboratory to avoid degradation. The microorganisms chosen to carry out this study were: a) Acetobacter pasteurianus KU710511 (CV01) isolated by Mounir et al., (2016c) from cactus; b) Lactobacillus plantarum S1 isolated by Mounir et al., from olive brine in 2016; and c) Saccharomyces cerevisiae LD01 isolated from Bouslikhen variety dates by Mounir et al., (2016a).

\subsection{Criteria for physico-chemical parameters}

In order to compare the effect of aeration on the quality and duration of the fermentation process, two types of fermentation (aerobic and anaerobic) were studied. In addition, optimal conditions for the synergy among the three strains selected for this study (LAB, yeast and $\mathrm{AAB}$ ) were assessed. Aerobic fermentation was achieved by introducing a central column into the vessel containing the brine and olives and through which the air bubbles were introduced to evacuate the $\mathrm{CO}_{2}$ produced during fermentation (Sánchez Gómez et al., 2006). According to Sánchez Gómez et al., 
(2006), LAB grow under these conditions only when the salt concentration is less than $8 \%$.

Due to bubbling air, the flow was controlled by a flowmeter adapted to the air inlet of a fermenter. Usually, the flow is fixed on the basis of past experience. When the active fermentation is complete (3-4 months), aeration is necessary only if the $\mathrm{CO}_{2}$ concentration and brine volume increase during the treatment (Sánchez Gómez et al., 2006).

\subsection{Implementation of the tests}

The olives were first washed and sorted to remove any damaged fruits. The experimental design was set up to study the effect of de-bittering, the effect of inoculation by yeasts, the effect of acid substitution with vinegar, the effect of acid substitution with acetic bacteria, and finally the effect of alternating aeration. The tests were compared to the conditions used in the industry and to those of artisanal fermentations in order to have a basis for comparison as described by (Kailis and Harris, 2007; El-Khaloui and Rahmani, 2012 ) (Table 1). The tests were carried out separately in glass vessels with one $\mathrm{kg}$ of olives brined in 2 liters of brine. Before inoculation into pilot fermentations, S. cerevisiae LD01 were grown in YPD broth at $30{ }^{\circ} \mathrm{C}$ aerobically for $48 \mathrm{~h}$ and L. plantarum $\mathrm{S} 1$ were grown in MRS broth at 30 ${ }^{\circ} \mathrm{C}$ aerobically for 24-36 h. YPD had the following composition: glucose $20 \mathrm{~g}$; casein peptone $10 \mathrm{~g}$; yeast extract $5 \mathrm{~g}$ and $1000 \mathrm{ml}$ of distilled water. 100 $\mathrm{mg}$ of chloramphenicol were added to the medium to inhibit bacterial growth (Beuchat 1992). GYEA medium was used to cultivate the $\mathrm{AAB}$ strain and was composed of $20 \mathrm{~g} / \mathrm{L}$ glucose, $5 \mathrm{~g} / \mathrm{L}$ yeast extract, $5 \mathrm{~g} / \mathrm{L}$ peptone of casein, $3 \%(\mathrm{w} / \mathrm{v})$ ethanol and $1 \%$ (w/v) acetic acid (Mounir et al., 2016c). The cells were then collected by centrifugation at $13000 \mathrm{rpm}$ at $4{ }^{\circ} \mathrm{C}$ and washed twice in saline solution $(0.85 \%$ $\mathrm{NaCl}$ ) (Zaragoza et al., 2017). The yeast and bacteria cells were adjusted to $10^{9}$ cells $/ \mathrm{ml}$ prior to inoculation into the olive brines. Then, the brine was inoculated to reach an estimated $10^{5}-10^{6}$ cells $/ \mathrm{mL}$ of each strain (inoculation with about $0.75 \%$ of seed cultures).

\subsubsection{Effect of de-bittering and vinegar suppletion on the fermentation process}

In this part of the experiment, the aim was to study the effect of lye treatment under anaerobic conditions as well as the effect of the acidification of the medium by the addition of $6 \%$ date vinegar. Samples were incubated at $30^{\circ} \mathrm{C}$. The lye treatment consisted of immersing the olives in a $\mathrm{NaOH}$ solution $(2 \%-3.5 \% \mathrm{w} / \mathrm{v})$, which penetrates up to two-thirds of the olive flesh (Fan and Hansen 2012). The lye treatment was followed by several water washings of the fruits with tap water to remove the residual lye and then the fermentation continued in the brine with $10.6 \%$ of $\mathrm{NaCl}$ under a $\mathrm{pH}$ adjusted to 3.5 using vinegar. Then the samples were divided into two groups: a group seeded both by $L$. plantarum S1 LAB strain $(0.75 \%)$ and $S$. cerevisiae LD01 strain (0.75\%) (Zaragoza et al., 2017 ) and a group seeded solely by the LAB strain $(0.75 \%)$. A control test was designed by reproducing the same conditions described previously except for the lye treatment.

\subsubsection{Effect of inoculation with Acetobacter pasteurianus KU710511 AAB strain under alternated aeration conditions}

The purpose of this part of the study is to highlight the effect of alternating aeration (aeration by air bubbling for eight hours a day) on the synergy among the three microorganisms used (LAB, AAB and yeast), investigated in vitro (in $6 \%$ brine) with different fermentation media (Table 1). The first assay was conducted under the optimal conditions of Acetobacter pasteurianus KU710511 AAB strain, namely: ethanol: $28.18 \mathrm{~g} / \mathrm{L}$ acetic acid: 10.12 $\mathrm{g} / \mathrm{L}$, glucose $15.15 \mathrm{~g} / \mathrm{l}$ and $\mathrm{pH}: 5.33$ as reported by Mounir et al., (2016c). The second assay was designed to ensure the optimal growth conditions of the Saccharomyces cerevisiae LD01 strain. The growth of the yeast strain was favored by the supplementation of the culture medium with glucose at a rate of $3 \mathrm{~g} / \mathrm{L}$.

\subsection{Fermentation monitoring}

\subsubsection{Physico-chemical analysis}

pH: was determined using a pH-meter "Eutech $\mathrm{pH} 1500$ ", next to a benzene beak. The $\mathrm{pH}$ was measured directly in the fermentation brine by rinsing the electrode with sterile distilled water between each of two determinations.

Titratable acidity: It was expressed as a percentage of lactic acid in the broth. It was determined by acid 
Table1. Class codes for each sample name and fermentation conditions

\begin{tabular}{|c|c|c|c|}
\hline Code & Test name & Conditions & References \\
\hline A & $\begin{array}{l}\text { Industrial } \\
\text { test }\end{array}$ & $\begin{array}{l}\text { - De-bittering }(1.3-2.0 \% \mathrm{NaOH}(\mathrm{w} / \mathrm{v})) 5-10 \mathrm{~h} \\
\text { - First wash }(2-3 \mathrm{~h}), 2 \mathrm{nd} \text { wash }(10-20 \mathrm{~h}) \\
\text { - Brining }(10.5-11.5 \% \mathrm{NaCl} \text { w/v); } \\
\text { - Acidification (citric acid, } \mathrm{pH} 4.0) \\
\text { - } 2 \text { hours maturation. } \\
\text { (Anaerobic condition) }\end{array}$ & $\begin{array}{l}\text { Kailis and Harris } 2007 \\
\text { Sánchez-Gómez et al., } \\
2006\end{array}$ \\
\hline B & $\begin{array}{l}\text { Traditional } \\
\text { test }\end{array}$ & $\begin{array}{l}\text { - Washing; } \\
\text { - Brining (12.0-15.0\% } \mathrm{NaCl} w / \mathrm{v}) \\
\text { - Renewing the brine every two to three days. } \\
\text { (Anaerobic condition) }\end{array}$ & $\begin{array}{l}\text { El-Khaloui and Rah- } \\
\text { mani } 2012\end{array}$ \\
\hline $\mathrm{C}$ & L1VS & $\begin{array}{l}\text { - De-bettering }(2 \% \mathrm{NaOH}) \\
\text { - Washing }(2 \mathrm{~h}-12 \mathrm{~h}) \\
\text { - Brining }(10.6 \% \mathrm{NaCl} \mathrm{w} / \mathrm{v}) \\
\text { - pH adjustment }(3.5) \\
\text { - Seeding with L. plantarum } \mathrm{S} 1(0.75 \%) \\
\text { (Anaerobic condition) }\end{array}$ & $\begin{array}{l}\text { Bousmaha et al., } 2010 \\
\text { Zaragoza et al., } 2017\end{array}$ \\
\hline $\mathrm{D}$ & L1V & $\begin{array}{l}\text { - De-bettering }(2 \% \mathrm{NaOH}) \\
\text { - Washing }(2 \mathrm{~h}-12 \mathrm{~h}) \\
\text { - Brining }(10.6 \% \mathrm{NaCl} w / \mathrm{v}) \\
\text { - pH adjustment }(3.5) \text {; } \\
\text { - Seeding with L. plantarum } \mathrm{S} 1(0.75 \%) \text { and S. cerevisiae LD01 }(0.75 \%) \text {. } \\
\text { (Anaerobic condition) }\end{array}$ & $\begin{array}{l}\text { Bousmaha et al., } \\
2010 \\
\text { Zaragoza et al., } 2017\end{array}$ \\
\hline $\mathrm{E}$ & $\mathrm{L} 2 \mathrm{~V}$ & $\begin{array}{l}\text { - Washing; } \\
\text { - Brining }(10.6 \% \mathrm{NaCl} \text { w/v); } \\
\text { - Adding vinegar to } \mathrm{pH}=3.5 \\
\text { - Seeding with } L . \text { plantarum } \mathrm{S} 1(0.75 \%) \\
\text { (Anaerobic condition) }\end{array}$ & $\begin{array}{l}\text { Bousmaha et al., } 2010 \\
\text { Zaragoza et al., } 2017\end{array}$ \\
\hline F & L2VS & $\begin{array}{l}\text { - Washing; } \\
\text { - Brining }(10.6 \% \mathrm{NaCl} w / \mathrm{v}) \\
\text { - Adding vinegar to } \mathrm{pH}=3.5 \\
\text { - Seeding with L. plantarum } \mathrm{S} 1(0.75 \%) \text { and S. cerevisiae LD01 }(0.75 \%) \text {. } \\
\text { (Anaerobic condition) }\end{array}$ & $\begin{array}{l}\text { Bousmaha et al., } 2010 \\
\text { Zaragoza et al., } 2017\end{array}$ \\
\hline G & L3V & $\begin{array}{l}\text { - Washing; } \\
\text { - Brining }(10.6 \% \mathrm{NaCl} \text { w/v); } \\
\text { - Seeding with } A \text {. pasteurianus } \mathrm{KU} 710511(0.75 \%) \text { in its optimal growth conditions; } \\
\text { - Seeding with } L . \text { plantarum } \mathrm{S} 1(0.75 \%) \text {; } \\
\text { (Alternated aeration condition: } 0.2 * \mathrm{~V} / \mathrm{h} ; 8 \mathrm{~h} / \text { day) }\end{array}$ & $\begin{array}{l}\text { Bousmaha et al., } 2010 \\
\text { Zaragoza et al., } 2017 \\
\text { Mounir et al., } 2016 \mathrm{~b} \\
\text { Pino et al., } 2018\end{array}$ \\
\hline $\mathrm{H}$ & L3VS & $\begin{array}{l}\text { - Washing; } \\
\text { - Brining }(10.6 \% \mathrm{NaCl} \text { w/v); } \\
\text { - Seeding with } A \text {. pasteurianus } \mathrm{KU} 710511(0.75 \%) \text { in its optimal growth conditions; } \\
\text { - Seeding with } L . \text { plantarum } \mathrm{S} 1(0.75 \%) \text { and } S \text {. cerevisiae LD01 }(0.75 \%) \text {. } \\
\text { (Alternated aeration condition: } 0.2 * \mathrm{~V} / \mathrm{h} ; 8 \mathrm{~h} / \text { day) }\end{array}$ & $\begin{array}{l}\text { Bousmaha et al., } 2010 \\
\text { Zaragoza et al., } 2017 \\
\text { Mounir et al., } 2016 \mathrm{~b} \\
\text { Pino et al., } 2018\end{array}$ \\
\hline I & L4V & $\begin{array}{l}\text { - Washing; } \\
\text { - Brining }(10.6 \% \mathrm{NaCl} w / \mathrm{v}) \\
\text { - Seeding with } L . \text { plantarum } \mathrm{S} 1(0.75 \%) \text { and } A \text {. pasteurianus KU710511 (0.75\%); } \\
\text { (Alternated aeration condition: } 0.2 * \mathrm{~V} / \mathrm{h} ; 8 \mathrm{~h} / \text { day) }\end{array}$ & $\begin{array}{l}\text { Bousmaha et al., } 2010 \\
\text { Zaragoza, et al., } 2017 \\
\text { Pino et al., } 2018\end{array}$ \\
\hline $\mathrm{J}$ & L4VS & $\begin{array}{l}\text { - Washing; } \\
\text { - Brining (10.6\% NaCl w/v); } \\
\text { - Seeding with L. plantarum } \mathrm{S} 1(0.75 \%) \text { and A. pasteurianus KU710511 }(0.75 \%) \text {; } \\
\text { - Seeding with } S . \text { cerevisiae LD01 }(0.75 \%) \text { in its optimal growth conditions } \mathrm{x} \text {; } \\
\text { (Alternated aeration condition: } 0.2 * \mathrm{~V} / \mathrm{h} ; 8 \mathrm{~h} / \text { day) }\end{array}$ & $\begin{array}{l}\text { Bousmaha et al., } 2010 \\
\text { Zaragoza et al., } 2017 \\
\text { Mounir et al., } 2016 \mathrm{c} \\
\text { Pino et al., } 2018\end{array}$ \\
\hline
\end{tabular}


base titration using N/9 sodium hydroxide solution in the presence of phenolphthalein as a colored indicator.

Determination of chloride: $\mathrm{NaCl}$ content was determined by titration of the concentration of the chloride ion in the brine according to Mohr's method (Sheen and Kahler 1938).

Determination of oleuropein: Prior to chromatographic analysis, the samples were prepared as follows: $1.5 \mathrm{~g}$ of olive flesh were mixed with $20 \mathrm{ml}$ of an 80:20 (v/v) solution of methanol/ water. The mixture was homogenized and then centrifuged at $3000 \mathrm{rpm}$ for $5 \mathrm{~min}$. The supernatant was then filtered through a filter paper and then passed through a $0.2 \mu \mathrm{m}$ supplementary filter. 20 $\mu \mathrm{l}$ of the extract were then injected into the HPLC following a method inspired by Tayoub et al., (2012). Briefly, chromatographic separation was carried out with an LC system coupled to a diode array detector (DAD), using a reversed phase C18 column (250 $\times 4.6,3.5 \mu \mathrm{m})$ at $35{ }^{\circ} \mathrm{C}$. The mobile phase was a mixture of water, acetonitrile and formic acid in the following proportions, respectively (84.6: $15: 0.4$ ). The flow rate of the mobile phase was $1 \mathrm{ml} / \mathrm{min}$ for an injection volume of $20 \mu \mathrm{L}$, with UV detection at $240 \mathrm{~nm}$.

\subsubsection{Microbiological analysis}

$\mathrm{LAB}$, yeasts and $\mathrm{AAB}$ were counted using MRS (De MAN et al., 1960), YPD (Mounir et al., 2016a) and GYEA (Mounir et al., 2016c) culture media, respectively. Enumeration was done after 24-48 hours incubation, by counting petri dishes with a number of colonies between 30 and 300 .

\subsection{Sensory evaluation of olives}

Sensory analysis was carried out on olive samples three days after the end of the experiment in order to classify them. Criteria such as external appearance, texture, odor and flavor were evaluated (Table 2). The sensory evaluation was carried out by a panel of 15 tasters composed of professors and students initiated into sensory food analysis ( 9 females, 6 males at 23-51 years of age), who consumed fermented table olives frequently. Before starting the evaluation, the panelists received a 2 -h training session for the sensory evaluation of table olive products and the necessary explanations to carry out this part of the study. All samples were coded with random 3-digit numbers. Pieces of bread were used to restore the taste by reducing the bitter and acidic sensations between two tastings. Each consumer was provided with thirty plates (10 trials with 3 repetitions each) individually and separately, containing five fruits of each treatment of table olive (Rababah et al., 2019). The sensory evaluation was facilitated using the answer sheet presented in the supplementary file 1 .

\subsection{Statistical analysis of the results}

XLSTAT software (2018.3 version) was used to perform a Factorial Correspondence Analysis (FCA) on the sensory analysis results. FCA aims to study the connection or the correspondence between the qualitative characteristics of a contingency table through graphical representations. To do this, ten products noted $\mathrm{A}$ to $\mathrm{J}$ were prepared using different

TABLE 2. Class codes for attributes used in sensory evaluation of fermented olives

\begin{tabular}{|c|c|c|}
\hline Attribute & Level & Code * \\
\hline \multirow{3}{*}{ External appearance } & Good & AEB \\
\hline & Normal & AEM \\
\hline & $\mathrm{Bad}$ & AEV \\
\hline \multirow{3}{*}{ Firmness } & Good & FM \\
\hline & Normal & FN \\
\hline & $\mathrm{Bad}$ & FD \\
\hline \multirow{3}{*}{ Odor } & Good & $\mathrm{OB}$ \\
\hline & Normal & $\mathrm{OM}$ \\
\hline & $\mathrm{Bad}$ & $\mathrm{OV}$ \\
\hline \multirow{3}{*}{ Salty flavor } & Good & SB \\
\hline & Normal & SM \\
\hline & Bad & SV \\
\hline \multirow{3}{*}{ Bitterness } & Good & $\mathrm{AmB}$ \\
\hline & Normal & $\mathrm{AmM}$ \\
\hline & Bad & $\mathrm{AmV}$ \\
\hline \multirow{3}{*}{ Altered flavor } & Good & $\mathrm{AlB}$ \\
\hline & Normal & Alm \\
\hline & Bad & AlV \\
\hline
\end{tabular}

* The code represents an abbreviation taking into account the nature of the sensory evaluation attribute and its level: AEB, AEM and $\mathrm{AEV}$, good, normal and bad external appearance, respectively; FM, FN and FD, good, normal and bad firmness, respectively; OB, $\mathrm{OM}$ and $\mathrm{OV}$, good, normal and bad odor, respectively; SB, SM and $\mathrm{SB}$, good, normal and bad salty flavor, respectively; AmB, AmM and AmV, good, normal and bad bitterness, respectively; AlB, Alm and AlV, slightly, moderately and formally altered flavor. 
combinations (Table 1). To evaluate the quality among these products six attributes were used with three levels for each one (good, medium and bad) as depicted in Table 2.

\section{RESULTS}

From more than 60 isolates, three microbial strains were selected to carry out experiments aimed at the preparation of natural table olives. These strains, namely : Lactobacillus plantarum S1, Saccharomyces cerevisiae LD01 and Acetobacter pasteurianus KU710511 (CV01) were identified using biochemical and molecular techniques and characterized in previous studies (Mounir et al., 2018; Mounir et al., 2016a; Mounir et al., 2016b; Mounir et al., 2016c) The determination of chloride, titratable acidity, $\mathrm{pH}$, and counts of LAB, yeasts and $\mathrm{AAB}$ were carried out using the methods described in the Material and methods section. Then, samples were presented to tasters to evaluate their organoleptic quality.

The Figure 1 shows that the $\mathrm{pH}$ of the traditional test remained between 5 and 5.5 throughout the experiment, with three relatively high values observed between the 40th and 55th day of the experiment. On the other hand, the titratable acidity, expressed in grams of lactic acid per liter started with an acidity of 1.7 at the beginning of the experiment, and gradually decreased to $0.09 \mathrm{~g} / \mathrm{l}$, as noted in the $40^{\text {th }}$ day. Then it started to increase continuously to reach 1.75 in the last days of the experiment.

Figure 2 shows the evolution of the number of Lactic Acid Bacteria and Yeast in the brine during the

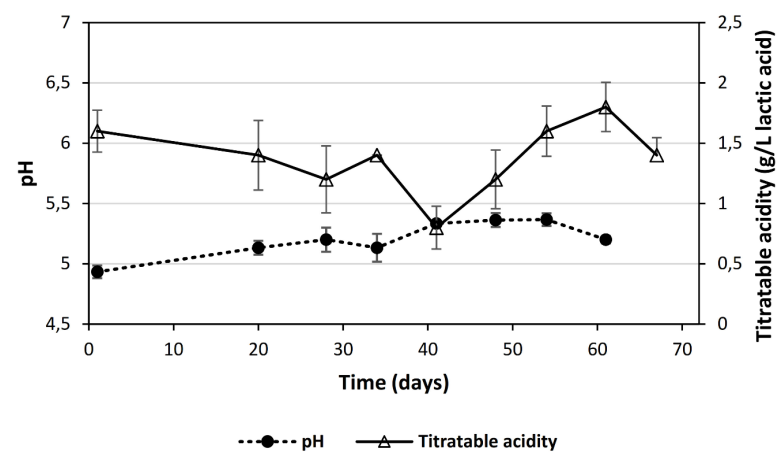

Figure1. Changes in the $\mathrm{pH}$ (circles) and titratable acidity (triangles) in $\mathrm{g} / \mathrm{L}$ lactic acid of the brine in traditional tests (brining with $12.0-15.0 \% \mathrm{NaCl} w / \mathrm{v}$ and renewing the brine every two to three days). Data points are mean values \pm standard deviation of triplicate samples. Error bars represent standard deviations of values and each value is significantly different at $\mathrm{p}<0.05$ according to the Tuky test.

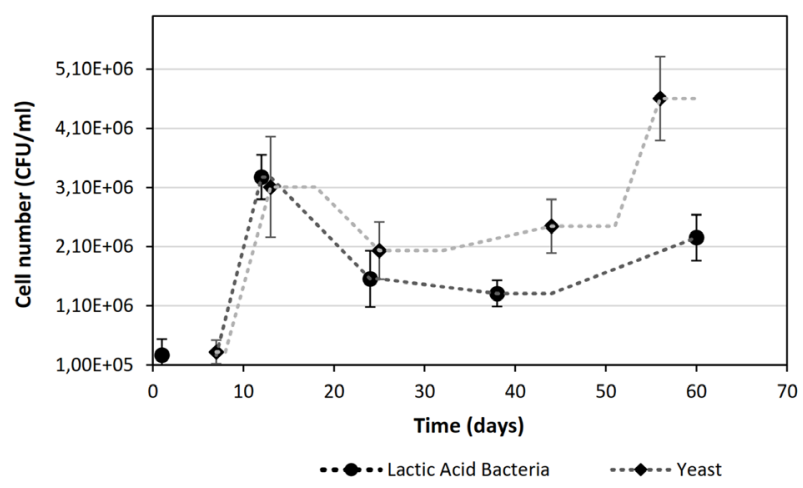

FiguRE 2. Evolution of the number of Lactic Acid Bacteria (circles) and Yeast (diamonds) in the brine during the spontaneous fermentation process of the traditional assay. Each value is an average of three determinations, mean \pm SD. Error bars represent standard deviations of values and each value is significantly different at $\mathrm{p}<$ 0.05 according to the Tuky test. Enumeration was carried out using the plate count method using the MRS and YPD media, respectively, for LAB and Yeast.

spontaneous fermentation process of the traditional assay. This figure reveals that the evolution pattern of the concentration of the two types of microorganisms was similar. The two groups of microorganisms had an average value of $3.2 \cdot 10^{5} \mathrm{CFU} / \mathrm{ml}$ during the first days of the experiment. The graph also shows that the concentration of the two groups changed by increasing to exceed $3 \cdot 10^{6} \mathrm{CFU} / \mathrm{mL}$ on the $12^{\text {th }}$ day, and decreased to around $2 \cdot 10^{6} \mathrm{CFU} / \mathrm{mL}$ between the $12^{\text {th }}$ and $23^{\text {th }}$ days. After that, the number of cells continued to increase slightly for the LAB strains; while the increase was much more significant for the yeast strains on the last 10 days to reach $4.7 \cdot 10^{6}$ $\mathrm{CFU} / \mathrm{mL}$ at the end of the experiment.

\subsection{Effect of de-bittering and vinegar suppletion on the fermentation process}

In this part of the study, de-bettering was performed with sodium hydroxide and two successive washes. After that, date vinegar, produced with the $S$. cerevisiae LD01 yeast strain along with the L. plantarum S1 LAB strain, was added to the $10.6 \%(\mathrm{w} / \mathrm{v}) \mathrm{NaCl}$ brine, all anaerobically. Then, three flasks were inoculated with the LAB strain only and three others were inoculated both with the $\mathrm{LAB}$ and yeast strains. This test was not seeded by the AAB strain, so we did not count it.

Figure 3 shows the effect of de-bittering on fermentation process parameters with and without inoculation with the $S$. cerevisiae strain. As can be seen from the graphs in Figure 3.A, the titratable acidity for samples not seeded by the $S$. cerevisiae 
A

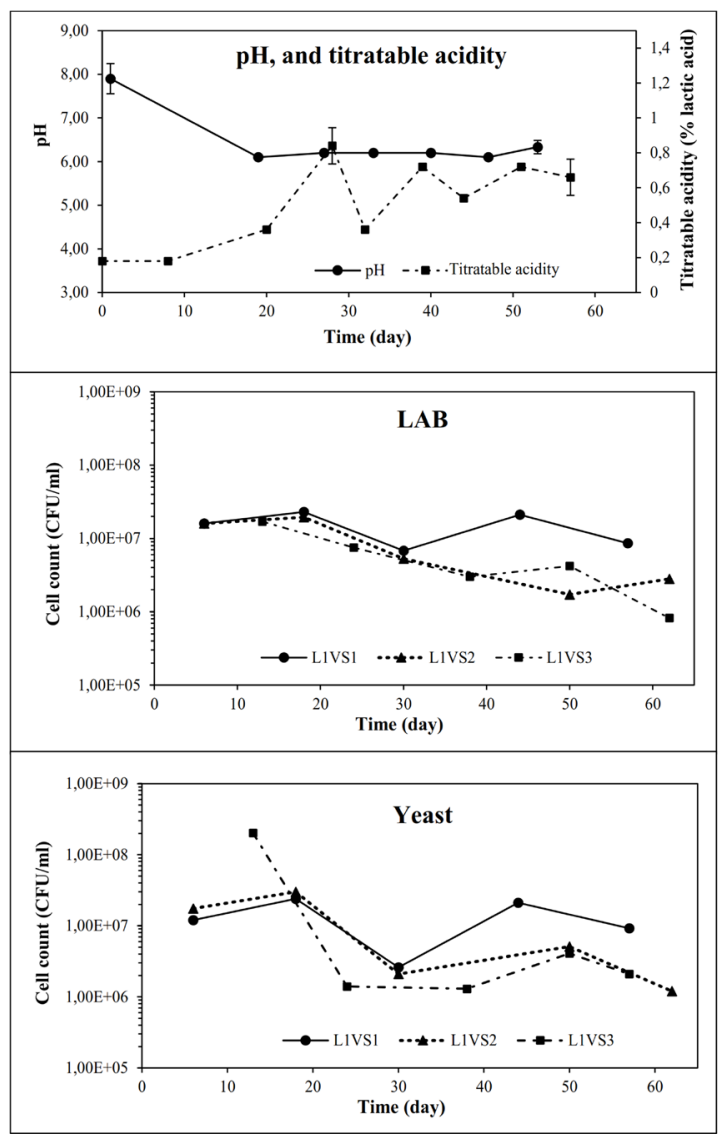

B
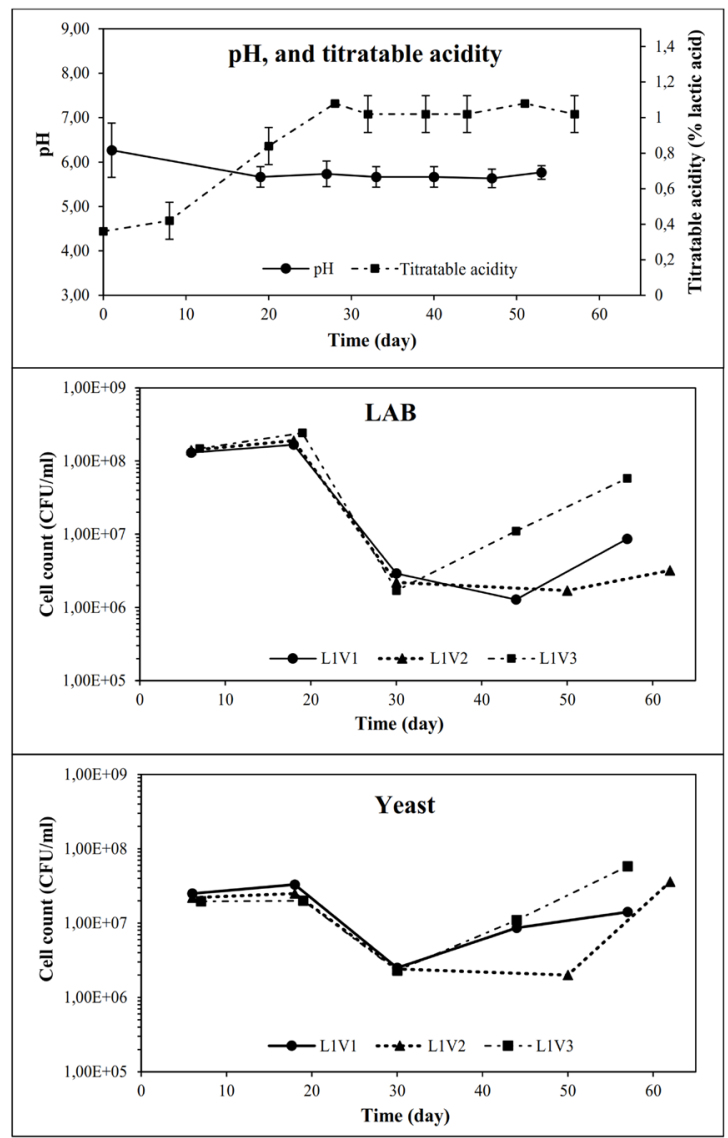

FigURE 3. Fermentation process parameters in de-bittered samples using 2-3.5\% w/v NaOH. Three replicates (L1V1, L1V2 and L1V3) were inoculated with $0.75 \%$ of $S$. cerevisiae LD01 strain (B), and three others were not (A) used as reference (L1VS1, L1VS2 and

L1VS3). All samples were inoculated with $0.75 \%$ of $L$. plantarum S1 LAB strain. The samples were prepared according to the descriptions given in Table 1 (test L1V and L1VS, respectively). The tests were carried out anaerobically with one $\mathrm{kg}$ of olives brined in 2-liter bottles. Cell numbers were determined by the plate count method using MRS and YPD media, respectively, for LAB and Yeast.

strain was $0.2 \mathrm{~g} / \mathrm{L}$ at the beginning of the experiment, then gradually increased to $0.8 \mathrm{~g} / \mathrm{L}$ lactic acid on the 27 th day and then varied at around $0.67 \mathrm{~g} / 1$ until the end of the experiment. For inoculated samples with the $S$. cerevisiae strain (Figure 3.B), the $\mathrm{pH}$ started with a value of 6.2 at the beginning of the fermentation cycle, then the $\mathrm{pH}$ stabilized at 5.8. The titratable acidity started with a value of $0.4 \mathrm{~g} / \mathrm{L}$ lactic acid and it then gradually increased from the 8th day to around $1 \mathrm{~g} / \mathrm{L}$ to be stabilized at this value afterwards. In this assay, the microbial count of the three repetitions monitored separately showed the same trend, especially during the first thirty days. The average of the initial values for the LAB strain in inoculated samples (Figure 3.B) was quite high (1.4. $10^{8} \mathrm{CFU} / \mathrm{mL}$ ), and a very slight increase was observed up to the $18^{\text {th }}$ day followed by a sudden drop until the $30^{\text {th }}$ day to be close to a concentration of $10^{6} \mathrm{CFU} / \mathrm{ml}$. A slight increase occurred during the last 30 days to reach a maximum value of $5.810^{7}$ $\mathrm{CFU} / \mathrm{ml}$ for the third repetition and around $5.9 \cdot 10^{6}$ $\mathrm{CFU} / \mathrm{mL}$ for the other two replicates (Figure 3.B).

On the other hand, Figure 3.B shows that the $S$. cerevisiae LD01 strain experienced similar growth for the 3 replicates, with an average concentration of $2.2 \cdot 10^{7} \mathrm{CFU} / \mathrm{mL}$, which remained more or less stable until the 20th day, followed by a decrease in concentration to arrive at $2.4 \cdot 10^{6} \mathrm{CFU} / \mathrm{mL}$. After that, the three repetitions experienced an increase in concentration with slopes that differed between each repetition to reach the end of the experiment at an average value of $3.610^{7} \mathrm{CFU} / \mathrm{mL}$. However, Figure 3.A shows that the LAB strain had an average growth value of $10^{7} \mathrm{CFU} / \mathrm{mL}$ at the beginning of the experiment, with a concentration of $2 \cdot 10^{8} \mathrm{CFU} /$ $\mathrm{mL}$ on the $13^{\text {th }}$ day for the third repetition. The 
concentration remained approximately at an average of $510^{6} \mathrm{CFU} / \mathrm{mL}$, then dropped slightly for the 3 samples to reach $9 \cdot 10^{6}, 1.2 \cdot 10^{6}$ and $2.1 \cdot 10^{6} \mathrm{CFU} /$ $\mathrm{mL}$ for the three repetitions, respectively. Figure 3.A also shows that the yeast concentration of the first repetition showed an overall decrease from $1.65 \cdot 10^{7}$ $\mathrm{CFU} / \mathrm{mL}$ to reach $8.6 \cdot 10^{6}, 2.80 \cdot 10^{6}$ and $8.2 \cdot 10^{5} \mathrm{CFU} /$ $\mathrm{mL}$, repetitively, for repetitions 1,2 and 3 .

The second experiment was conducted with acidification of the brine with $10.6 \%(\mathrm{~m} / \mathrm{v})$ date vinegar produced in the lab using the selected yeast and AAB strains. The fermentation was carried out under anaerobic conditions. Three flasks were inoculated with the LAB strain (L2V1, L2V2 and L2V3) and three others were inoculated with the LAB and yeast strains (L2VS1, L2VS2, L2VS3). Microbiological counting of this test gave no results for lactic acid bacteria and yeasts during the first days of the experiment.

In samples not inoculated with $S$. cerevisiae (Figure 4.A), the starting $\mathrm{pH}$ was 3.9 , which was adjusted by the addition of vinegar, then the $\mathrm{pH}$ increased to an average value of 4.5 on the $19^{\text {th }}$ day. Then, from the $20^{\text {th }}$ day, the $\mathrm{pH}$ fluctuated between 4.5 and 5 until the end of the experiment. For titratable acidity, the average starting value was $3.18 \mathrm{~g} / \mathrm{L}$ lactic acid, and it then slightly decreased until the 28th day with $3.00 \mathrm{~g} / 1$ and then stabilized at an average value of $3.50 \mathrm{~g} / 1$. For microbial growth, the curves obtained for the three repetitions did not keep the same pace. However, we noticed that there was a slightly positive effect on the growth of LAB but an insignificant effect on the growth of endogenous yeasts (Figure 4).
A
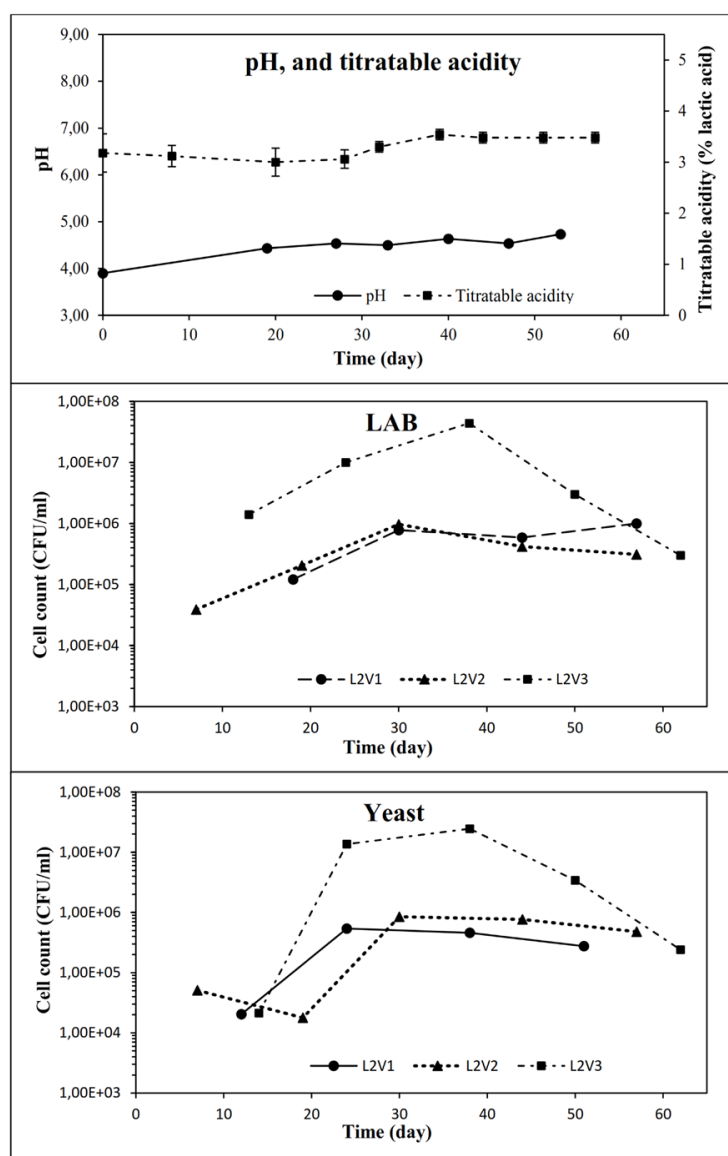

B
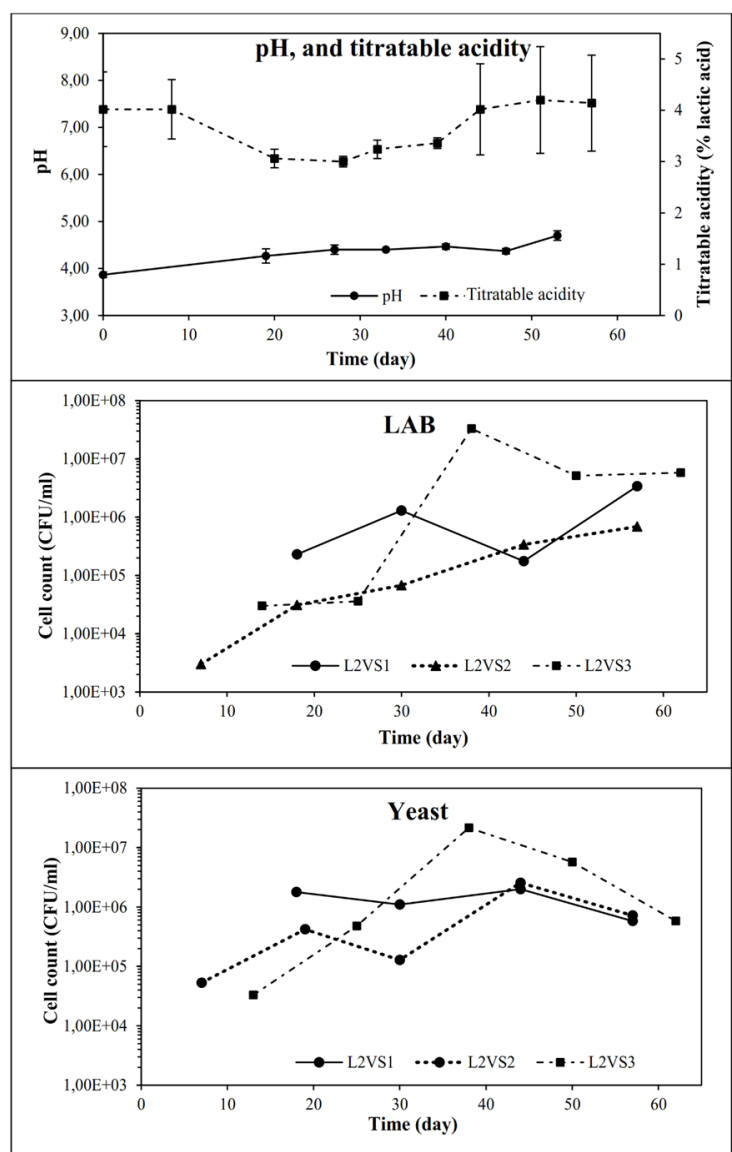

FIGURE 4. Fermentation process parameters in non de-bittered samples with acidification of the brine with $10.6 \%(\mathrm{~m} / \mathrm{v})$ date vinegar. Three replicates (L2VS1, L2VS2, L2VS3) were inoculated with $0.75 \%$ of S. cerevisiae LD01 strain (B), and three others were not (A) used as reference (L2V1, L2V2 and L2V3). All samples were inoculated with $0.75 \%$ of $L$. plantarum S1 LAB strain. The samples were prepared according to the description provided in Table 1 (test L2VS and L2V respectively). The tests were carried out anaerobically with one $\mathrm{kg}$ of olives brined in 2-liter bottles. Cell numbers were determined by the plate count method using MRS and YPD media, respectively for $\mathrm{LAB}$ and Yeast. 


\subsection{Alternated aeration effect on microbial growth in the brine of naturally fermented olives}

The olives of this test were prepared in brine at $6 \%(\mathrm{w} / \mathrm{v}) \mathrm{NaCl}$ under the optimal conditions of A. pasteurianus KU710511 strain with alternating aeration at a rate of $0.2 \mathrm{xV} / \mathrm{h}$ and 8 hours per day. Three flasks were seeded with $\mathrm{LAB}$ and $\mathrm{AAB}$ strains (L3V1, L3V2, L3V3) and three others with LAB, $\mathrm{AAB}$ and the yeast strains (L3VS1, L3VS2, L3VS3).

A shown in Figure 5A, the $\mathrm{pH}$ was around 3.9 during the first 28 days, and increased substantially to be stabilized at around 5.2 from day 40 . The acidity started with an average value of $13.5 \mathrm{~g} / \mathrm{L}$ of lactic acid and dropped significantly and stabilized at an average of $3 \mathrm{~g} / \mathrm{L}$. The $\mathrm{pH}$ was around 3.9 during the first 28 days for samples that were inoculated with the yeast strain (Figure 5.B), and increased significantly to about 5.5 by the end of the experiment. The acidity started with an average value of $16 \mathrm{~g} / \mathrm{L}$ of lactic acid and dropped significantly and stabilized at an average value of 2.9.

We also noted that during the first days of the experiment, the yeasts showed an average growth of $8.35 \cdot 10^{5} \mathrm{CFU} / \mathrm{mL}$ and then increased to around $8 \cdot 10^{9}$ CFU/mL. Subsequently, the yeasts of L3V1 fell to

\section{A}

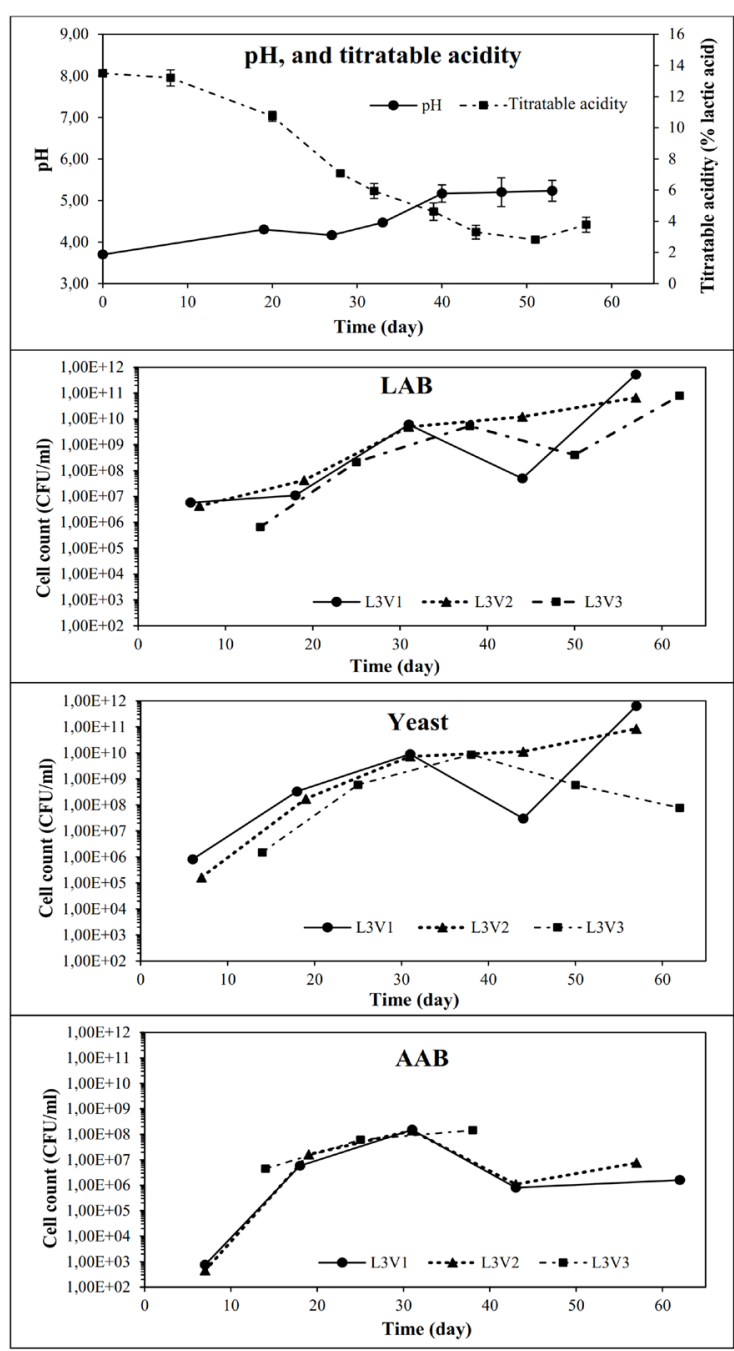

B

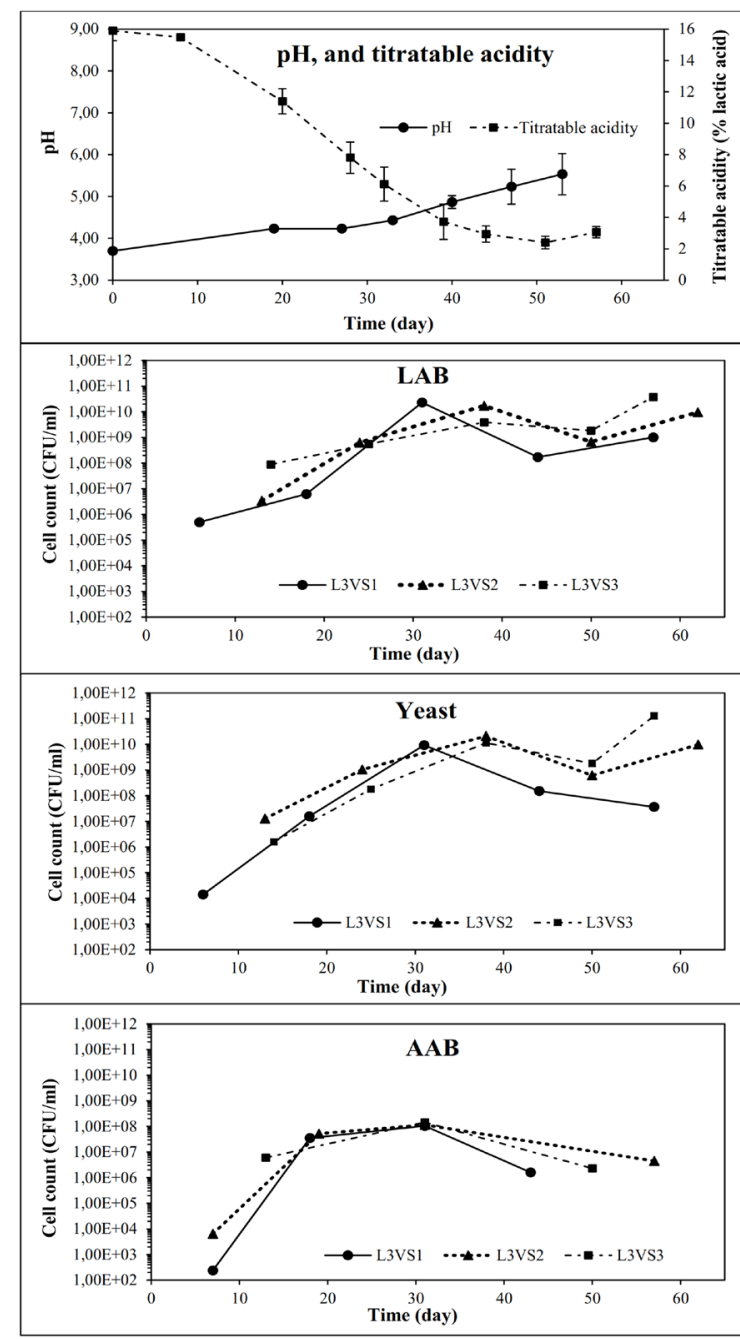

FIGURE 5. Fermentation process parameters of naturally fermented samples under alternating aeration and inoculation by $\mathrm{AAB}$ strain conditions. Three replicates (L3VS1, L3VS2 and L3VS3) were inoculated with $0.75 \%$ of S. cerevisiae LD01 strain (B), and three others were not (A) used as reference (L3V1, L3V2 and L3V3). All samples were inoculated with A. pasteurianus KU710511 (0.75\%) and with L. plantarum S1 LAB strain (0.75\%). The samples were prepared according to the description provided in Table 1 (test L3VS and L3V, respectively). Cell numbers were determined by the plate count method using MRS and YPD media, respectively, for LAB and Yeast. 
$3 \cdot 10^{7} \mathrm{CFU} / \mathrm{mL}$ on the $44^{\text {th }}$ day, increasing to $6.4 \cdot 10^{11}$ $\mathrm{CFU} / \mathrm{mL} 13$ days later. Those of L3V2 continued their progressive rise to arrive at $8.510^{10} \mathrm{UFC} / \mathrm{mL}$ towards the end $\left(57^{\text {th }}\right.$ day). L3V3 peaked on the 38th day at $8.7 \cdot 10^{9}$ and dropped to $7.8 \cdot 10^{7} \mathrm{CFU} / \mathrm{mL}$ on day 62 . Whereas, the LAB strain exhibited a growth of approximately $5 \cdot 10^{6} \mathrm{CFU} / \mathrm{ml}$ at the beginning of the experiment, then gradually increased to an average value of $2.21 \cdot 10^{11} \mathrm{CFU} / \mathrm{mL}$ towards the end of the experiment with an intermediate increase at around $5.8 \cdot 10^{9} \mathrm{CFU} / \mathrm{mL}$ on day 31 for $\mathrm{L} 3 \mathrm{~V} 1$ and on day 38 for L3V3. On the other hand, the AAB strain started at very low concentrations (about $10^{3} \mathrm{CFU} /$ $\mathrm{mL}$ ), and subsequently increased to around $10^{8} \mathrm{CFU} /$ $\mathrm{mL}$ by the 30th day. Subsequently, the concentration decreased to be stable at $5 \cdot 10^{6} \mathrm{CFU} / \mathrm{mL}$ from the $42^{\text {nd }}$ day to the end of the experiment.

However, Figure 5B shows that the yeast strain showed a growth of $1.4 \cdot 10^{4} \mathrm{CFU} / \mathrm{mL}$ for the L3VS1 test at day 6 . As for the L3VS2 and L3VS3 repetitions, the first determination made on the 13th day gave an average of $7.2 \cdot 10^{6} \mathrm{CFU} / \mathrm{mL}$. Subsequently, the L3VS2 and L3VS3 replicates ranged from around $5 \cdot 10^{9} \mathrm{CFU} / \mathrm{mL}$; while L3VS1, after reaching a maximum of $9.310^{9} \mathrm{CFU} / \mathrm{ml}$, gradually decreased to $3.7 \cdot 10^{7} \mathrm{CFU} / \mathrm{mL}$ at the 57 th day. The LAB strain had a cell concentration of approximately $5 \cdot 10^{5} \mathrm{CFU} / \mathrm{mL}$ at the beginning of the experiment, then gradually increased to an average value of approximately $1.62 \cdot 10^{10} \mathrm{CFU} / \mathrm{mL}$ towards the end of the experiment with an intermediate increase to around $1.5 \cdot 10^{10}$ $\mathrm{CFU} / \mathrm{mL}$ on the 36 th day. Finally, the AAB strain started at very low concentrations (about $10^{3}$ ), and subsequently increased to around $10^{8}$ by the 30th day. Subsequently the concentration decreased to be stable at $3.5 \cdot 10^{6} \mathrm{CFU} / \mathrm{mL}$ towards the end of the experiment.

\subsection{Organoleptic evaluation of produced olives}

The contingency table (supplementary file 2) contains the frequencies of the tasters who noted the different quality criteria of the samples by classifying them as "good", "medium" or "bad". Criteria were then subjected to Factorial Correspondence Analysis. The calculation of eigenvalues indicates that the variation shares explained by axis 1 and axis 2 were $50.1 \%$ and $22.6 \%$, respectively. The main plane constituted by these two axes therefore alone accounted for $72.7 \%$ of the total variation of the cloud of points (Figure 6). The projection of the line points (10 samples) and the column points (quality criteria) in the main plane is shown in Figure 6. Examination of this figure indicates that:

The vertical axis F2 opposes the group formed by the samples C, D, A, G and $\mathrm{H}$ characterized by good appearance, good bitterness and quite normal firmness to the samples B, E and F, which have opposite characteristics, namely a normal to bad external appearance, a hard firmness and a quite pronounced bitterness. The horizontal axis F1 opposes the group formed by the samples $\mathrm{G}$ and $\mathrm{H}$, characterized by a good smell and a normal salty flavor compared to the group formed by A, C and D, which is characterized by a normal to bad odor and a medium to bad salty flavor. Samples I and J were close to the center and are therefore not very well presented by this plan. However, it can be said that they have good appearance with a good smell to bad, fairly strong bitterness and hard firmness.

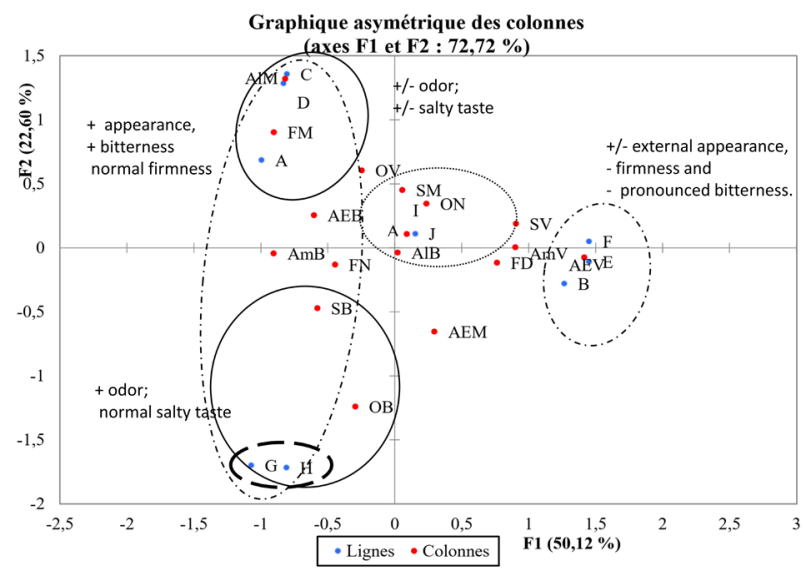

Figure 6. Graphical representation of the results of a Factorial Correspondence Analysis (FCA) of the sensory evaluation of the fermented olives: projection in factorial axes 1 and 2 of fermented olives groups (A, B, C, D, E, F, G, H, I and J (Table 1)), regarding classes of the qualitative attributes (External appearance, firmness, odor, salty flavor, bitterness and altered flavor (Table 2)). The vertical axis opposes the group formed by the samples C, D, A, $\mathrm{G}$ and $\mathrm{H}$, which are characterized by good appearance, good bitterness and normal firmness as compared to the samples B, E and F, which had opposite characteristics (dash-point). The horizontal axis opposes the group formed by the samples $\mathrm{G}$ and $\mathrm{H}$, which are characterized by good attributes compared to the group formed by $\mathrm{A}, \mathrm{C}$ and $\mathrm{D}$ (solid line). $\mathrm{G}$ and $\mathrm{H}$ samples were expected to be the most highly appreciated ones.

\section{DISCUSSION}

In this study, four different combinations were applied to the "Picholine marocaine" olive variety 
using indigenous strains, namely Lactobacillus plantarum S1, Saccharomyces cerevisiae LD01 and Acetobacter pasteurianus KU710511 (CV01).

First, we noted that the greater or lesser variability between the repetitions of the same test at the level of the microbiological characteristics can be due to the moment of analysis. Since these were not carried out at the same time for the three repetitions (considering our human and material resources), we opted for the separation of repetitions over time by taking all the necessary precautions (operator, material and environment effects).

The traditional test was the only one where the brine was changed regularly (every three days), which may explain the variability in the microbiological results of the three repetitions, and also the fact that the $\mathrm{pH}$ alternatively varied from around 5.3 throughout the experiment. This behavior was also observed for titratable acidity. We also noted that the increase in microbial count, both for LAB and yeast strains, was not very pronounced since after a first value of about $2 \cdot 10^{5} \mathrm{CFU} / \mathrm{mL}$ there was an increase to reach $10^{6} \mathrm{CFU} / \mathrm{mL}$, then there was stagnation around this value throughout the experiment.

Results found by Zaragoza et al., (2017) revealed that the introduction of exogenous spoilage yeast and LAB into olive fermentations caused significant but distinct alterations in the numbers and diversity of microbes associated with the olives and brines. According to the microbial evolution of tests 1 and 2 (Table 1), we noted that the acidity had a more severe effect on the microbial concentration than the basicity, indeed this concentration was very weak or even null in the first days of experiment for test 2 (supplemented by vinegar). Whereas for test 1 , where $\mathrm{pH}$ values were around 6 to 7 (because of $\mathrm{NaOH}$ residues), the population was relatively high and even reached $10^{8} \mathrm{CFU} / \mathrm{mL}$ at the beginning of the experiment but dropped gradually after a few days.

We also noted that alternate aeration increased the concentration of the LAB and the yeast strains, since for the anaerobic tests, it did not exceed $10^{7} \mathrm{CFU} /$ $\mathrm{ml}$; whereas for tests 3 and 4 (alternating aeration) it reached $10^{11} \mathrm{CFU} / \mathrm{mL}$. A possible relationship between $\mathrm{LAB}$ and yeasts during the fermentation of olives in brine was reported by (Heperkan 2013). In addition to the LAB usually used in this kind of fermentation, the use of Saccharomyces cerevisiae yeast as a starter is justified by the role that it can play in the fermentation of olives by producing ethanol, ethylacetate, acetaldehyde and other compounds responsible for the development of olive flavors (Ciafardini and Zullo, 2019; Fernandez Escobar et al., 2013).

On the other hand, it was demonstrated that fermentation in altered aeration mode, served to modify the metabolic pathway of $L$. plantarum by promoting the conversion of lactate into acetate (Bobillo and Marshall 1991). Indeed, acetic acid can inhibit the growth of gram-negative strains which are responsible for the degradation of table olives during storage (Makras and De Vuyst 2006). In addition, this process allowed us to use lower concentrations of $\mathrm{NaCl}(6 \% \mathrm{w} / \mathrm{v})$ compared to the concentrations used in anaerobic fermentations ( 10 to $15 \% \mathrm{w} / \mathrm{v}$ ). Reducing salt in the processing of olives is always a goal. In fact, a diet that is low in sodium and high in potassium and calcium is recommended to lower blood pressure and to protect against osteoporosis, colon cancer, and cardiovascular diseases (Degirmencioglu, 2016).

The combination of alternating aeration, the use of optimal growth conditions of the $\mathrm{AAB}$ strain and the chosen $\mathrm{NaCl}$ concentration served to create a synergy among the three strains which led to the elaboration of table olives with very good organoleptic quality and in a fairly short time (40 days).

On the other hand, for test 4, the use of alternating aeration with the same $\mathrm{NaCl}$ concentration as test 3 was not sufficient to obtain good olives after 60 days of fermentation. This finding suggests that this trial required more time, despite the high $\mathrm{LAB}$ and yeast populations (of the same order of magnitude as in test 3), suggesting that the AAB strain plays a vital role in the success of fermentation by creating the synergy necessary to obtain table olives with good sensory quality in a relatively short time. Indeed, aerobic fermentation is generally used to avoid the appearance of a deterioration called "gaseous pockets" which is manifested by the swelling of the skin caused by accumulation of gas under the epidermis of the olive (Lanza 2013). In addition, AAB strain could adjust the acidity of the medium and thus promote the onset of fermentation by providing yeasts and lactic acid bacteria with favorable conditions for their development by continuously eliminating the ethanol produced by the yeast and thus maintaining an acceptable level of $\mathrm{pH}$ by producing acetic acid (Hammoucha and Taleb, 2017). 
Concerning the industrial test, lye de-bettering resulted in olives without bitterness and a good appearance, although the texture was judged as normal to soft. On the other hand, the L3V test led to both a very good taste, a normal texture and a salinity which was very much appreciated compared to the industrial test.

\section{CONCLUSION}

The objective of the work was to contribute to the development of a method for the preparation of natural table olives using locally selected microorganisms and without resorting to chemical additives. The effects of the parameters, essentially inoculation with Lactobacillus plantarum S1, Saccharomyces cerevisiae LD01 and Acetobacter pasteurianus KU710511 strains and alternating aeration were assessed. The samples were inoculated with pure suspensions of these microorganisms and then monitored over time using the plate count method. Only molecular analyses could provide accurate data on the survival of the selected starters during fermentation, but the inoculated tests by selected strains most likely contributed to reach those $\mathrm{CFU} / \mathrm{ml}$ numbers as they were inoculated in a high number at the beginning of the fermentations.

It has been reported previously that acetic acid, the main product of oxidative fermentation by $\mathrm{AAB}$ in ethanol, is a compound that has a positive correlation with the growth of yeasts and could have an accelerating effect on LAB growth (Pino et al., 2018). The results obtained served to confirm that the aerobic fermentation normally used for the elimination of the deterioration of table olives due to "gas pockets" can also be used to create the conditions necessary for the introduction of the acetic acid bacteria which are strict aerobes in the fermentation process of the olives. In addition, alternated aeration conditions allowed for increasing the cell biomass during fermentation and the use of a lower concentration of $\mathrm{NaCl}$ compared to anaerobic fermentation.

The microbiological, physicochemical and sensory analyses carried out demonstrated the possibility of introducing a new process for producing natural table olives. In this method, we used a starter composed of two strains, namely Acetobacter pasteurianus KU710511 (CV01) and Lactobacillus plantarum $\mathrm{S} 1$ under the optimal conditions of $\mathrm{AAB}$ growth as reported by Mounir et al., (2016b) with $6 \% \mathrm{NaCl}$ and alternating aeration of 8 hours/day.

\section{ACKNOWLEDGMENTS}

We would like to express our sincere gratitude to Mostafa Cheheb, laboratory technician, for his valuable help and constructive suggestions during the planning and development of this work.

\section{REFERENCES}

Amer A, Faiz ul-Hassan N, Kashfa B, Aasia B. 2017. Microbial $\beta$-Glucosidase: Sources, Production and Applications. J. Appl. Env. Microbiol 5, 3146. https://doi.org/10.12691/JAEM-5-1-4

Anon. 2016. International olive council. Conclusions IOC Conf. COP22. Available at: http://www. internationaloliveoil.org/news/view/686-year2016news/787-conclusions-of-the-ioc-conferenceat-cop22?lang=fr_FR [Accessed July 20, 2017].

Beuchat LR. 1992. Media for detecting and enumerating yeasts and moulds. Int. $J$. Food Microbiol. 17, 145-158. https://doi. org/10.1016/0168-1605(92)90112-G

Bobillo M, Marshall VM. 1991. Effect of salt and culture aeration on lactate and acetate production by Lactobacillus plantarum. Food Microbiol. 8, 153-160. https://doi.org/10.1016/07400020(91)90008-P

Bousmaha L, El Yachioui M, Ouhssine M. 2010. Amélioration du procédé de fermentation traditionnelle des olives vertes. Afrique Sci. Rev. Int. des Sci. Technol. 5, 114-125.

Campus M, Degirmencioglu N, Comunian R. 2018. Technologies and trends to improve table olive quality and safety. Front. Microbiol. 9. https:// doi.org/10.3389/fmicb.2018.00617

Chemonics International, Inc. 2007. Guide De Bonnes Pratiques De Fabrication Des Olives De Table, Agriculture and Agrobusiness Intégrés, USAID-Maroc, Repport n. 071, pp.1-42.

Ciafardini G, Zullo BA. 2019. Use of selected yeast starter cultures in industrial-scale processing of brined Taggiasca black table olives. Food Microbiol. 80, 103250. https://doi.org/10.1016/j. fm.2019.103250

Cleenwerck I, De Vos P. 2008. Polyphasic taxonomy of acetic acid bacteria: an overview of the currently applied methodology. Int. J. Food Microbiol. 125, 2-14

Colmagro S, Collins G, Sedgley M. 2001. Processing Technology of the Table Olive. 
in Jules J, (Ed.) Horticultural Reviews. John Wiley and Sons, Inc, pp. 235-242. https://doi. org/10.1002/9780470650783.ch5

Degirmencioglu N. 2016. Modern Techniques in the Production of Table Olives. in Boskou D, Clodoveo ML, (Ed.) Products from Olive Tree. IntechOpen, pp. 215-234. https://doi. org/10.5772/64988

El-Khaloui M, Nouri A. 2007. Procédés d'élaboration des olives de table à base des variétés Picholine marocaine et Dahbia. Transfert de Technologie en Agriculture 037, 77-80.

El-Khaloui M, Rahmani M. 2012. Ypicité des préparations traditionnelles d'olives de table dans la province d'Ouazzane. Transfert de Technologie en Agriculture 197, 1-5.

Fan L, Hansen LT. 2012. Fermentation and biopreservation of plant-based foods with lactic acid bacteria. Handb. Plant-Based Fermented Food Beverage Technol. Second Ed., 35-48. https://doi.org/10.1201/b12055-5

Faid M. (n.d.). Beware of eating red olives / Mohamed Faid - YouTube. Retrieved April 6, 2020, from https://www.youtube.com/watch?v=yJoUDDsy$\mathrm{c} 0 \& \mathrm{t}=75 \mathrm{~s}$

Fernandez Escobar R, de la Rosa R, Leon L. 2013. Evolution and sustainability of the olive production systems. Options Méditerranéennes. Séries A Mediterr. Semin. 106, 11-41.

Hammoucha J, Taleb O. 2017. Contribution à l'amélioration des conditions de fermentation des olives de table. Institut Agronomique et Vétérinaire Hassan II, Rabat. Maroc

Heperkan D. 2013. Microbiota of table olive fermentations and criteria of selection for their use as starters. Front. Microbiol. 4, 1-11. https:// doi.org/10.3389/fmicb.2013.00143

KailisS,HarrisDJ.2007.Producingtableolives,Landlinks Press. https://doi.org/10.1071/9780643094383

Kavroulakis N, Ntougias S. 2011. Bacterial and $\beta$-proteobacterial diversity in Olea europaea var. mastoidis- and $O$. europaea var. koroneikigenerated olive mill wastewaters: Influence of cultivation and harvesting practice on bacterial community structure. World J. Microb. Biotechnol. 27 (1), 57-66. https://doi.org/10.1007/s11274-0100426-3

Lanza B. 2013. Abnormal fermentations in tableolive processing: Microbial origin and sensory evaluation. Front. Microbiol. 4, 1-7. https://doi. org/10.3389/fmicb.2013.00091

Makras L, De Vuyst L. 2006. The in vitro inhibition of Gram-negative pathogenic bacteria by bifidobacteria is caused by the production of organic acids. Int. Dairy J. 16, 1049-1057. https:// doi.org/10.1016/j.idairyj.2005.09.006

Man JC de, Rogosa M, Sharpe ME. 1960. A edium for the cultivation of Lactobacilli. $J$. Appl. Bacteriol. 23, 130-135. https://doi. org/10.1111/j.1365-2672.1960.tb00188.x

Marsilio V, Campestre C, Lanza B. 2001. Phenolic compounds change during California-style ripe olive processing. Food Chem. 74, 55-60. https:// doi.org/10.1016/S0308-8146(00)00338-1

Mounir M, Fauconnier ML, Afechtal M, Thonart P, Ismaili Alaoui M, Delvigne F. 2018. Aroma profile of pilot plant-scale produced fruit vinegar using a thermo-tolerant Acetobacter pasteurianus strain isolated from Moroccan cactus. Acetic Acid Bact. 7, 1-11. https://doi. org/10.4081/aab.2018.7312

Mounir M, Belgrire M, Lahnaoui S, Hamouda A, Thonart P, Delvigne F, Ismaili Alaoui M. 2016a. Maîtrise de la fermentation alcoolique sous stress éthanolique, thermique et osmotique de la souche Saccharomyces cerevisiae YSDN1 en vue de la préparation du vinaigre de fruits. Rev. Marocaine Sci. Agron. Vétérinaires 4, 86-95.

Mounir M, Shafiei R, Zarmehrkhorshid R, Hamouda A, Thonart P, Delvigne F, Ismaili Alaoui M. 2016b. Optimization of biomass production of Acetobacter pasteurianus KU710511 as a potential starter for fruit vinegar production. African J. Biotechnol. 15, 1429-1441. https://doi. org/10.5897/AJB2016.15323

Mounir M, Shafiei R, Zarmehrkhorshid R, Hamouda A, Ismaili Alaoui M, Thonart P. 2016c. Simultaneous production of acetic and gluconic acids by a thermotolerant Acetobacter strain during acetous fermentation in a bioreactor. J. Biosci. Bioeng. 121, 166-171. https://doi. org/10.1016/j.jbiosc.2015.06.005

Pino A, De Angelis MD, Todaro A, Van Hoorde KV, Randazzo CL, Caggia C. 2018. Fermentation of Nocellara Etnea table olives by functional starter cultures at different low salt concentrations. Front. Microbiol. 9. https://doi.org/10.3389/ fmicb.2018.01125 
Rababah T. 2019. Sensory properties of green table olives prepared by different fermentation processes. CYTA - J. Food 17, 997-1005. https:// doi.org/10.1080/19476337.2019.1693430

Ramírez E, Medina E, García P, Brenes M, Romero C. 2017. Optimization of the natural debittering of table olives. LWT - Food Sci. Technol. 77, 308313. https://doi.org/10.1016/j.lwt.2016.11.071

Rokni Y, Ghabbour N, Chihib NE, Thonart P, Asehraou A. 2015. Physico-chemical and microbiological characterization of the natural fermentation of moroccan picholine green olives variety. J. Mater. Environ. Sci. 6, 1740-1751.

Rincón-Llorente B. 2018. Table olive wastewater: Problem, treatments and future strategy. A review. Front. Microbiol. 9. https://doi.org/10.3389/ fmicb.2018.01641

Sánchez Gómez AH, García García P, Rejano Navarro L. 2006a. Trends in table olive production Elaboration of table olives. Grasas Aceites 57 (1), 86-94. https://doi.org/10.3989/ gya.2006.v57.i1.24

Shahidi F, Kiritsakis A eds. 2017. Olives and Olive Oil as Functional Foods, John Wiley \&amp; Sons, Ltd, Chichester, UK. https://doi. org/10.1002/9781119135340

Sheen HT, Kahler HL. 1938. Effect of ions on Mohr method for chloride determination. Ind. Eng. Chem. Anal. Ed. 10, 628-629. https://doi. org/10.1021/ac50127a004

Tayoub G, Sulaiman H, Hassan AH, Alorfi M. 2012. Determination of Oleuropein in leaves and fruits of some Syrian olive varieties. Int. J. Med. Aromat. Plants 2, 428-433.

Valero A, Medina E, Arroyo-López FN. 2017. Microbial hazards and their implications in the production of table olives. in Singh O V, (Ed.) Foodborne Pathogens and Antibiotic Resistance. John Wiley \& Sons, Inc, pp. 119-138. https://doi. org/10.1002/9781119139188.ch5

Zaragoza J, Bendiks Z, Tyler C, Kable ME, Williams TR, Luchkovska Y, Chow E, Boundy-Mills K, Marco ML. 2017. Effects of Exogenous Yeast and Bacteria on the Microbial Population Dynamics and Outcomes of Olive Fermentations. MSphere 2, 1-14. https://doi.org/10.1128/ mSphere.00315-16 